\title{
Impact of anesthesia for cancer surgery: Continuing Professional Development
}

\author{
James S. Green, MBBS • Ban C. H. Tsui, MD
}

Published online: 29 October 2013

(c) Canadian Anesthesiologists' Society 2013

\begin{abstract}
Purpose A number of original publications and review articles have addressed the issue of perioperative immune modulation and cancer outcome. The objective of this module is to review current understanding surrounding the pathways involved and the evidence implicating commonly used anesthetic agents.

Principal findings Drugs commonly used in anesthetic practice have been shown to affect various components of the immune system in laboratory animal and human in vitro models. It has been hypothesized that these effects may favour tumour recurrence and metastasis formation. Inhalational agents and opiates have potential negative immunomodulatory effects; on the other hand, regional anesthesia and propofol may have positive effects on immune function modulation. However, the clinical relevance of these studies to human cancer outcome is unknown since clinical trials are equivocal, and results of in vitro and animal model studies cannot be extrapolated to clinical practice. Furthermore, there is a lack of rigorous clinical trials demonstrating clinical outcome benefit for one technique over another. It remains unclear how anesthetic drugs influence the immune system in relation to tumour cell elimination and clinical cancer outcome.
\end{abstract}

\footnotetext{
Author contributions James Green and Ban Tsui made substantial contributions to conception and design and analysis and interpretation of data; drafting the article and revising it critically for important intellectual content; and final approval of the version to be published.
}

J. S. Green, MBBS · B. C. H. Tsui, MD ( $\square)$

Department of Anesthesiology and Pain Medicine, University of Alberta, 8-120 Clinical Sciences Building, Edmonton,

AB T6G 2G3, Canada

e-mail: btsui@ualberta.ca
Conclusions Recommendations for a specific anesthetic technique based on cancer outcome alone cannot be made. A pragmatic solution would be to offer regional anesthesia in isolation or combined with propofol infusion to cancer patients if appropriate and if local expertise is available. Regional anesthesia offers excellent analgesia, a low incidence of postoperative nausea and vomiting, and a favourable immunological profile based on current understanding of laboratory evidence.

\section{Objectives of this Continuing Professional Development (CPD) module:}

After reading this module, the reader should be able to:

1. Outline the pathways involved in perioperative immune modulation;

2. Identify commonly used anesthetic and analgesic drugs associated with altered cell-mediated immunity;

3. Evaluate the limitations of current laboratory and clinical evidence in this field;

4. Inform patients about our current understanding of this subject.

The concept of cancer immunosurveillance was proposed in the $1950 \mathrm{~s},{ }^{1}$ and it is now recognised that the immune system plays an important protective role against cancer growth. ${ }^{2}$ Elimination of tumour cells by the immune system involves cell-mediated immunity (CMI), including activation of phagocytes, cytotoxic T-lymphocytes, and cytokine release, resulting in tumour cell destruction. Laboratory-based research using animal and human in vitro models points towards altered CMI following surgery, and suppression of the immune system during the 
perioperative period may be sufficient to allow tumour cells to escape immunosurveillance and metastasize. ${ }^{3}$ Perioperative factors thought to cause immunosuppression include the surgical stress response, pain, anxiety, hypothermia, blood transfusion, and anesthetic drugs. ${ }^{4,5}$ Thus, a variety of factors modulate the immune system towards a more positive or negative cancer outcome.

A possible link between anesthetic technique and cancer outcome in humans was hypothesised in 1977 following a retrospective review of 1,358 breast cancer patients. ${ }^{6}$ Survival rates of patients receiving halothane were considerably greater than those receiving ether. In 2006, a retrospective review of 129 patients undergoing mastectomy and axillary clearance for breast cancer reported that both recurrence- and metastasis-free survival were significantly greater in the paravertebral analgesia group than in the morphine analgesia group. ${ }^{7} \mathrm{~A}$ number of related basic science, clinical, and review publications followed these papers, yet the question remains: how far has our knowledge of the relationship between anesthesia, the immune system, and cancer advanced?

In order to determine the clinical significance of the anesthetic technique, it is necessary to review the current hypotheses linking perioperative stressors to immune modulation and metastasis growth. It is also important to understand the challenges researchers face in this area and the limitations of current laboratory and clinical evidence. In this module, we review both basic scientific and clinical evidence with respect to the relationship between anesthetics and perioperative drugs, immune function, and cancer with the aim of elucidating the knowledge required to fully inform patients of our current understanding of this subject and to guide clinical practice.

\section{Immunosurveillance and tumour modulation - an introduction to the key components}

Neurohumoral stress response

An acute inflammatory response develops at the site of surgical trauma (Fig. 1). When pain is transmitted centrally, activation of the hypothalamus and sympathetic nervous system results in a rise in plasma cortisol, catecholamines, acetylcholine, and peptides with subsequent depression of both innate (Natural Killer (NK) cells [a subgroup of cytotoxic lymphocytes], monocytes, macrophages, and dendritic cells) and specific (cytotoxic CD8 T and helper CD4 T lymphocytes) CMI. ${ }^{8}$ Helper CD4 $\mathrm{T}$ lymphocytes include Th1 and Th2 subgroups: Th1 cells enhance the cell-mediated elimination response towards tumour cells, while Th2 cells promote a humoral, antibody-mediated response which does not have a role in tumour elimination (Fig. 2). An increased Th1:Th2 cell ratio indicates an enhanced CMI response and would be potentially beneficial for tumour elimination, while a decreased ratio may favour tumour progression. Cytokines are produced by most nucleated cells, including those involved in CMI, in response to stressors such as trauma and infection. Cytokine production is dependent on the type of immune response, and certain cytokines such as IFN-gamma, IL-2, and TNF are associated with a Th1 cell-mediated response. In contrast cytokines such as IL4, IL6, IL10, and IL13 are associated with a Th2 antibody response. Prostaglandin E2 (PGE2), a product of the cyclooxygenase (COX) pathway, modulates the immune system by selectively suppressing macrophage, neutrophil, Th1, and NK cell function while promoting a $\mathrm{Th} 2$ response.

\section{Angiogenesis}

Surgery can result in shedding of tumour cells into the blood and lymphatics. These cells have the potential to form metastases in the capillary beds of distant organs. For a tumour to survive beyond $2 \mathrm{~mm}$ in size, angiogenesis must occur. ${ }^{9}$ Vascular endothelial growth factor (VEGF) is one of many cytokines known to play an important role in this process.

Metastatic breast cancer growth includes periods of temporary dormancy, and surgical resection of the primary tumour may disrupt these dormant periods resulting in relapse. Decreased production of the anti-angiogenic factors angiostatin and endostatin upon removal of the primary tumour results in increased levels of VEGF, thus promoting angiogenesis. Release of matrix metalloproteinases (MMP) during surgery also increases the motility and invasive capacity of free malignant cells, ${ }^{10}$ contributing to metastasis growth. Animal studies have shown that inhibition of VEGF receptor activity can reduce colon cancer liver metastasis. ${ }^{11}$ Inhibition of angiogenesis has also been used in clinical practice with some success, but a number of patients have refractory disease. In others, tumours quickly develop resistance to anti-angiogenic factors, and adverse drug-related events can also prevent successful treatment. Single nucleotide polymorphisms (SNP) in the VEGF gene may alter VEGF protein concentrations in individual patients, influencing angiogenesis. $^{12}$ These SNPs may therefore account for the variation in the clinical course of angiogenesisdependent tumours such as breast, non-small cell lung, colorectal, ${ }^{13}$ and prostate cancers. 


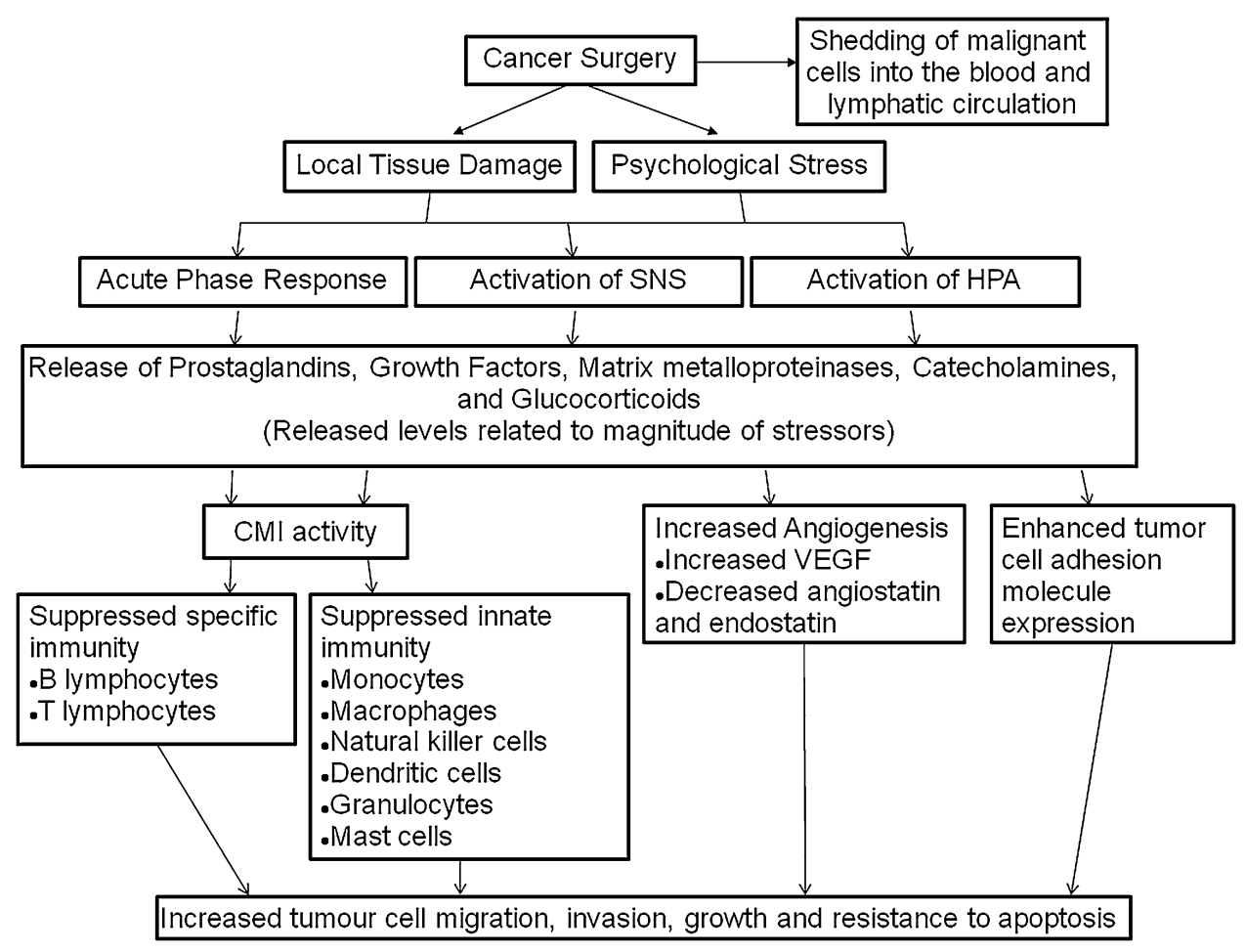

Fig. 1 Interaction between surgery and the immune system. SNS = sympathetic nervous system; HPA = hypothalamopituitary axis; $\mathrm{CMI}=$ cell-mediated immunity; VEGF $=$ vascular endothelial growth factor

Fig. 1 Interaction entre la chirurgie et le système immunitaire. SNS = système nerveux sympathique; HPA = axe hypothalamo-hypophysaire; ICM = immunité à médiation cellulaire; VEGF $=$ Facteur de croissance de l'endothélium vasculaire

\section{Agents and techniques directly implicated in immunosuppression - basic science evidence}

Induction agents

\section{Thiopental}

Thiopental has been demonstrated to have immunosuppressive properties in both human and animal studies. Human studies reveal dose-dependent decreases in T-lymphocyte proliferation ${ }^{14}$ and depression of monocyte cytolysis, ${ }^{15}$ while animal studies show a significant increase in tumour retention ${ }^{16,17}$ and reduced numbers of NK cells compared with control. ${ }^{16}$

\section{Propofol}

Propofol may have a more favourable immunomodulating profile than other induction agents in terms of CMI modulation. When using propofol for maintenance of anesthesia in craniotomy patients, no significant reduction in Th1:Th2 ratio was seen. ${ }^{18}$ Propofol has also been shown to suppress monocytic PGE2 production via an effect on COX activity.

\section{Etomidate}

Evidence is limited but supports a negative effect of etomidate on the immune system. A human study showed a dose-dependent reduction in proliferation of T-lymphocytes following exposure to etomidate. ${ }^{14}$

\section{Ketamine}

The evidence for ketamine is mixed. A human study showed that low dose ketamine prior to induction of anesthesia prevented a significant suppression of lymphocyte proliferation. ${ }^{19}$ Immunological effects appear to be dose-dependent. Animal studies have shown a significant increase in lung tumour retention with larger doses $;{ }^{16}$ however, pre-treatment with a beta-blocker reduced this effect, suggesting involvement of ketamine's intrinsic adrenergic stimulating properties. In another animal model, higher ketamine concentrations caused suppression of macrophage phagocytosis and oxidative ability in addition to a reduction of mitochondrial membrane potential, leading to mitochondrial dysfunction. $^{20}$ 


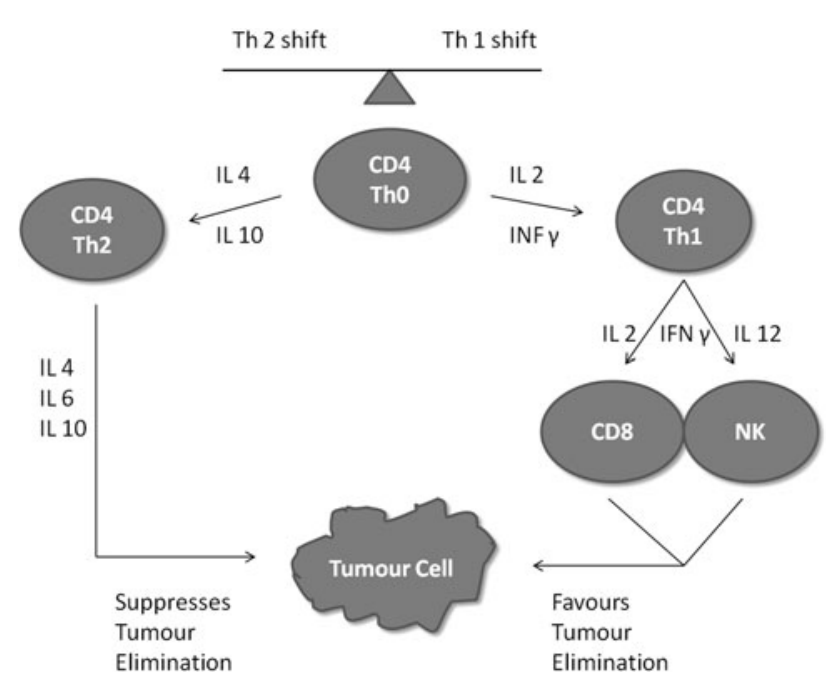

Fig. 2 A shift in balance of the Th1:Th2 ratio determines the immune response to cancer. A shift toward the Th1 response favours elimination of tumour cells, while a shift towards the Th2 response is immunosuppressive. Adapted from reference $\#^{34}$

Fig. 2 Un déplacement de l'équilibre du rapport Th1/Th2 détermine la réponse immunitaire envers le cancer. Un déplacement vers la réponse Th1 favorise l'élimination des cellules tumorales tandis qu'un déplacement vers la réponse Th2 est immunosuppressive. D'après la référence ${ }^{34}$

\section{Benzodiazepines}

Evidence for an effect of benzodiazepines on immune function is limited; however, anxiolytics should exert an overall beneficial effect on immunity through the reduction of stress. An animal model showed a decrease in Lewis lung carcinoma metastases in anxious, but not non-anxious, mice following treatment with diazepam. ${ }^{21}$

\section{Inhalational agents}

Inhalational agents have generally been associated with a reduction in CMI. Human studies showed a significant reduction in Th1:Th2 ratio when isoflurane was compared with propofol. ${ }^{18}$ In vitro experiments revealed DNA damage to human peripheral blood lymphocytes in a dose-dependent manner following exposure to halothane, isoflurane, sevoflurane, and desflurane. Volatile anesthetics are known to upregulate expression of hypoxia-inducible factors, which are important for maintaining normal cellular function in hypoxic conditions but which are also associated with tumorigenesis and poor cancer prognosis. ${ }^{22,23}$

Sevoflurane may have advantages over older inhalational agents. A reduced stress response (measured by adrenocorticotropic hormone, cortisol, and growth hormone levels) was evident when sevoflurane was compared with isoflurane for laparoscopic pelvic surgery. $^{24}$ Inhalational agents may also have beneficial effects; in an animal model, preconditioning with sevoflurane and desflurane was associated with a reduction in matrix metalloproteinase-9 release from isolated human neutrophils and reduced invasion of colorectal cancer cells.

Analgesics

\section{Opioids}

In animal models, morphine has been shown to increase suppression of NK cells and increase the tumour burden following surgery. ${ }^{25}$ The suppression of $\mathrm{NK}$ cells is dose-dependent, and the magnitude of effect is different between opiates (morphine $>$ fentanyl $>$ buprenorphine) ${ }^{26}$ Interestingly, ketorolac and interleukin-2 were found to reverse suppression of $\mathrm{NK}$ cells. ${ }^{25}$ In another animal model, two weeks of chronic morphine treatment resulted in stimulation of COX-2 and PGE2, increased tumour weight, increased metastasis, and reduced survival. These effects were prevented by co-administration of celecoxib. ${ }^{27}$

In human studies, intrathecal morphine $0.5 \mathrm{mg}$ suppressed NK cell activity on day one post-surgery, with recovery by day two. Suppression was not seen with $0.1 \mathrm{mg}$ morphine, also suggesting a dose-dependent effect. $^{28}$ Fentanyl administration has been associated with a transient increase in NK cell numbers, ${ }^{29}$ a dosedependent reduction in $\mathrm{NK}$ cell activity, ${ }^{30}$ or no reduction. $^{31}$ Remifentanil was not found to impair NK cell activity in healthy volunteers. ${ }^{32}$

Most of the immune effects of morphine are lost in $\mathrm{Mu}$-opioid receptor (MOR) knockout mice, indicating that MOR is the principal route for direct immunosuppression. Central MOR activation by opioids activates the descending pathways of the hypothalamopituitary axis (HPA) and the sympathetic nervous system (SNS), leading to immunomodulation. ${ }^{33}$ The mu3-receptor variant is sensitive to morphine but not fentanyl. Activation by morphine has been shown to have a negative effect on neutrophil function, an effect also not seen with fentanyl. ${ }^{34}$ A possible link is provided by the observation that the peripheral $\mathrm{mu}$ receptor antagonist methylnaltrexone inhibits morphine VEGF-induced angiogenesis and reduces human breast, colorectal, and non-small cell lung tumour growth in vitro. ${ }^{34}$

Clinically relevant doses of morphine have been shown to promote tumour neovascularisation and increased tumour progression in a human breast tumour xenograft mouse model. ${ }^{35}$ Opiates can also stimulate angiogenesis and induce a defect in barrier function (increasing vascular permeability), potentially allowing penetration of tumour cells. $^{36}$ 


\section{Non-steroidal anti inflammatory drugs (NSAID)}

Laboratory evidence suggests a potentially beneficial role for NSAIDs in cancer surgery. These drugs and selective COX-2 inhibitors, including celecoxib, inhibit the production of PGE2. In a murine breast cancer model, celecoxib prevented some of the adverse effects associated with chronic morphine use such as an increase in tumour weight, increase in metastasis, and reduction in survival. Additionally, indomethacin decreased lung mammary adenocarcinoma metastasis associated with surgery by $50 \%$ in a rat model. Indomethacin in combination with a beta-blocker reduced metastasis by $75 \%$. Further studies showed that PGE2 and beta-agonists independently increased metastasis and suppressed NK cell activity. ${ }^{25,37-39}$

\section{Acetaminophen}

No literature was identified regarding acetaminophen and immunosuppression.

\section{Tramadol}

Tramadol is a mu opioid receptor agonist as well as a serotonin and norepinephrine reuptake inhibitor. It may have benefits over morphine and codeine in terms of immunological effects. A review of animal models showed an increase in NK cell activity and increased lymphocyte proliferation following tramadol administration. ${ }^{33}$ In contrast to morphine, tramadol was not found to cause a dose-dependent reduction in phagocytic activity of peripheral polymorphonuclear cells and monocytes in a human in vitro study. ${ }^{40}$ Sacerdote et $a{ }^{41}{ }^{41}$ reported that postoperative treatment with tramadol, but not morphine, returned lymphocyte proliferation (which is depressed following surgery) to pre-surgery levels in patients undergoing abdominal surgery. This study also demonstrated enhanced activity of NK cells in the Tramadol group.

\section{Gabapentin}

Gabapentin, a GABA analog is used to treat neuropathic pain and has been used for perioperative analgesia. No literature was identified regarding gabapentin and immunosuppression.

Local anesthetic agents

In vitro experiments have shown local anesthetics to be cytotoxic at high concentrations. Duration of local anesthetic exposure and lipid solubility of the drug are thought to be important factors. ${ }^{42}$ However, the relevance of this finding in terms of cancer modulation is unclear since in clinical practice local anesthetic infiltration or intravenous infusion is not associated with sufficient concentration and duration to cause tumour cell death. A human study compared intraoperative lidocaine infusion with saline placebo in patients undergoing transabdominal hysterectomy and found that pain scores and cytokine production were lower in the lidocaine group, while lymphocyte proliferation response was greater than in the control group. ${ }^{43}$ Amide local anesthetics have also been found to inhibit lung adenocarcinoma cell migration. ${ }^{44}$

Regional anesthesia

A meta-analysis of studies which assessed NK cell function in the context of neuraxial anesthesia suggested both positive and negative effects on cell function with an overall neutral impact. ${ }^{45}$ Combined epidural and general anesthesia for hepatectomy was shown to be more effective than general anesthesia alone at enhancing the Th1 response, ${ }^{46}$ and in an animal study, addition of a spinal block to general anesthesia for laparotomy helped restore the activity of liver mononuclear cells (including NK and NK T cells), thereby reducing the risk of surgery-induced metastasis. ${ }^{47}$

\section{Other drugs}

\section{Beta-blockers}

A role for perioperative beta-blockade to improve postoperative immune function has been suggested to attenuate activation of the SNS. In an animal model, beta-1 and beta- 2 blockade was additive in preventing suppression of NK cell activity and increasing resistance to NK-sensitive metastasis. ${ }^{48}$

\section{Anti-emetic agents}

Dexamethasone is known to suppress thymic function, inducing thymic atrophy and causing changes in both the relative proportion and absolute number of thymocytes. ${ }^{49}$ A systematic review of dexamethasone concluded that a single dose for prevention of postoperative nausea and vomiting (PONV) suppresses all immune cell function for a brief period. ${ }^{50}$ Dexamethasone has been shown to reduce production of PGE2 at the site of surgical incision, which may indirectly support lymphocyte function. ${ }^{50}$ No evidence was found regarding serotonin 5HT3 receptor antagonists or histamine $\mathrm{H} 1$ receptor antagonists and immunosuppression. Metoclopramide has been shown to restore immune function after trauma-hemorrhage-induced immunosuppression and sepsis. ${ }^{51-53}$ Droperidol was shown to have no adverse effect on the generation of reactive oxygen species by $\mathrm{T}$ lymphocytes. ${ }^{54}$ Substance P inhibitors 
such as aprepitant are increasingly available in Canada for PONV prophylaxis use in high risk patients. They are antagonists of neurokinin 1 (NK1) receptors, ${ }^{55}$ which also modulate pain transmission in the dorsal horn, giving an additional advantage in terms of analgesia. Breast carcinoma cells express NK1 receptors, and antagonism blocks an additional pathway involved in tumour cell proliferation, migration, and angiogenesis, making this group of anti-emetics an interesting focus for further research.

\section{Proton pump inhibitors/H2 receptor antagonists}

Proton pump inhibitors reduce the bactericidal activity of neutrophils and inhibit NK cell activity. In contrast, ranitidine enhances NK cell activity and increases Th1:Th2 ratio. ${ }^{56-59}$ A prospective, randomized study of abdominal surgery patients found that ranitidine diminished the postoperative reduction in spontaneous and stimulated NK cell activity but did not significantly change the Th1:Th2 ratio or mononuclear cell responses. ${ }^{57}$

\section{Alpha-2 adrenoceptor agonists}

Alpha-2 receptors are expressed in breast tumour cells, and stimulation is associated with increased proliferation. ${ }^{9}$ Clonidine reduces NK cell activity compared to fentanyl in vitro.

\section{Neuromuscular blocking agents}

There is no evidence for direct effects of neuromuscular blocking agents on the immune system.

Surgical technique and management

The magnitude of surgical trauma is thought to be related to the degree of stress response, subsequent immunosuppression, and outcome. ${ }^{60}$ In patients with renal cell carcinoma, retroperitoneal laparoscopic radical nephrectomy was associated with significantly less immunosuppression compared to open radical nephrectomy. ${ }^{61}$ Other studies have demonstrated the benefits of video-assisted thoracoscopic surgery over thoracotomy on immune function and cancer outcome. ${ }^{60}$ Elevated hematological levels of tumor cells were found in approximately $30 \%$ of patients following surgical resection or radiotherapy for hepatocellular carcinoma. ${ }^{62}$

Blood transfusion can cause suppression of CD4 and CD8 cells. $^{34}$

Hypothermia decreases lymphocyte migration, reduces neutrophil phagocytosis, and favours a Th2 shift. ${ }^{34}$

\section{Agents and techniques directly implicated in immunosuppression - clinical evidence}

The potential for CMI to influence cancer outcome was highlighted in a prospective study assessing disease recurrence and survival in 77 total mastectomy patients. $^{63}$ Outcome data were compared with the patients' CMI responses to autologous tumourassociated antigens (TAA; proteins that are expressed differently in cancer cells $v s$ normal cells) in the early post-operative period. Twenty-one patients had a positive cell-mediated immune response to autologous TAA. Only one patient died from metastatic disease. Fifty-six patients had a negative response, and 23 died from metastatic disease. It appears, therefore, that certain patients may be more at risk of developing disease recurrence and metastasis based on CMI response to autologous TAA. There may be a subset of patients where CMI function is predictive of long term outcome.

Clinical evidence supporting a benefit of regional anesthesia in terms of cancer outcome and recurrence is conflicting and consists of a mixture of retrospective reviews and follow-up of randomized controlled trials (RCTs) that were originally designed to answer different hypotheses. The primary source of interest was a retrospective study comparing outcomes of patients undergoing mastectomy who received general anesthesia combined with either paravertebral anesthesia/analgesia or postoperative morphine analgesia. ${ }^{7}$ Survival at 24 months without recurrence and/or metastasis was $94 \%$ in the paravertebral group compared with $82 \%$ in the morphine group; the survival rates were $94 \%$ and $77 \%$ at 36 months, suggesting a potential benefit for the paravertebral group. A retrospective study involving patients with invasive prostatic carcinoma undergoing open radical prostatectomy, general anesthesia was given with either epidural analgesia or opioid analgesia, and the risk of recurrence was lower in the epidural group. ${ }^{64} \mathrm{~A}$ benefit was also seen in retrospective studies of melanoma and ovarian, hepatocellular, and colorectal cancers. It should be noted that other retrospective studies have been published that show no difference between regional and general anesthesia (see Table). Follow-up reviews of previously conducted RCTs showed no difference for prostate surgery and conflicting results for colorectal surgery.

There is epidemiological evidence that the use of aspirin and other NSAIDs is associated with a reduction in incidence of malignancies, including breast cancer. ${ }^{65} \mathrm{~A}$ retrospective review of breast cancer patients undergoing mastectomy suggested that intraoperative ketorolac use was associated with decreased cancer recurrence. ${ }^{66}$ 


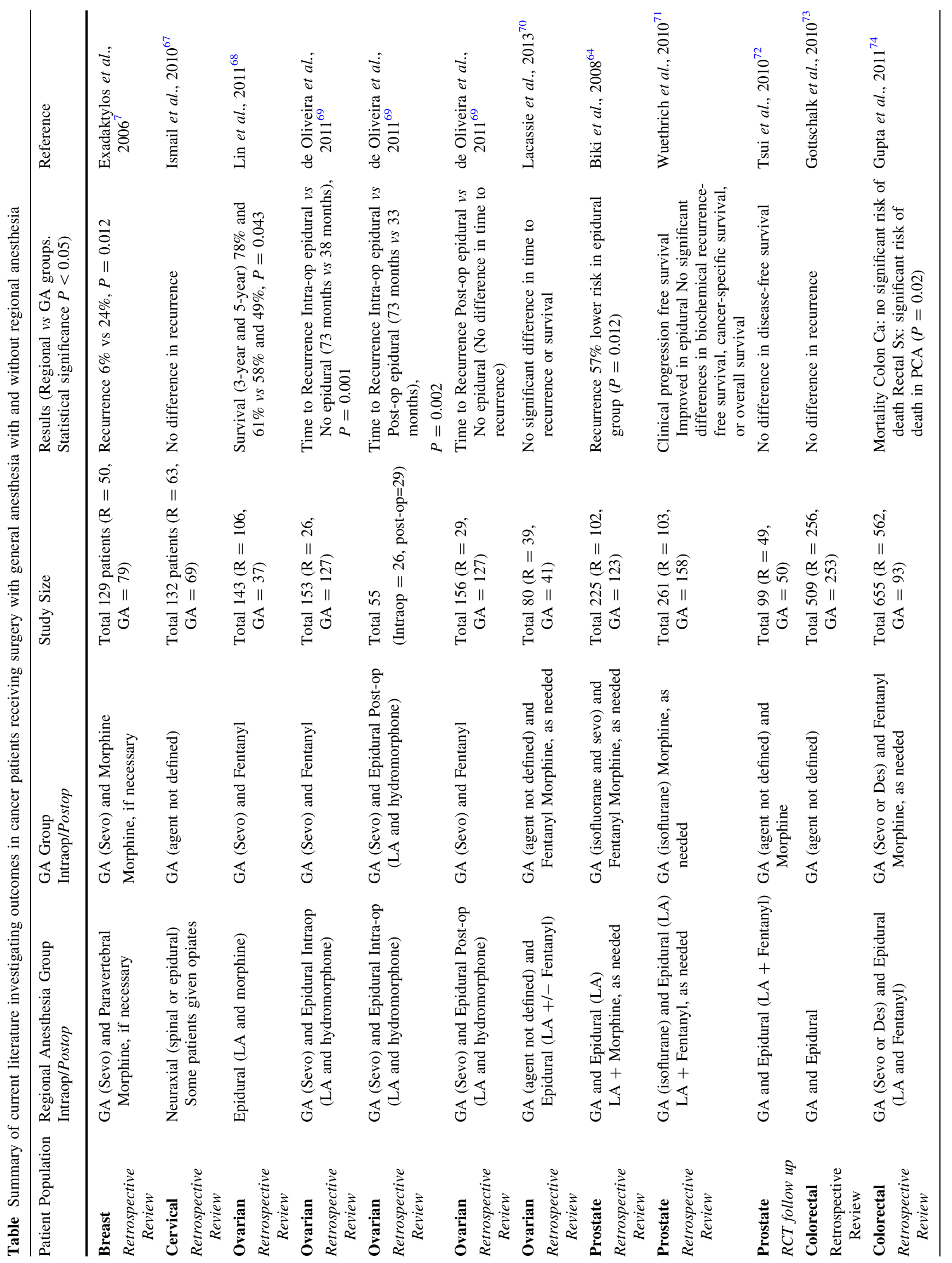




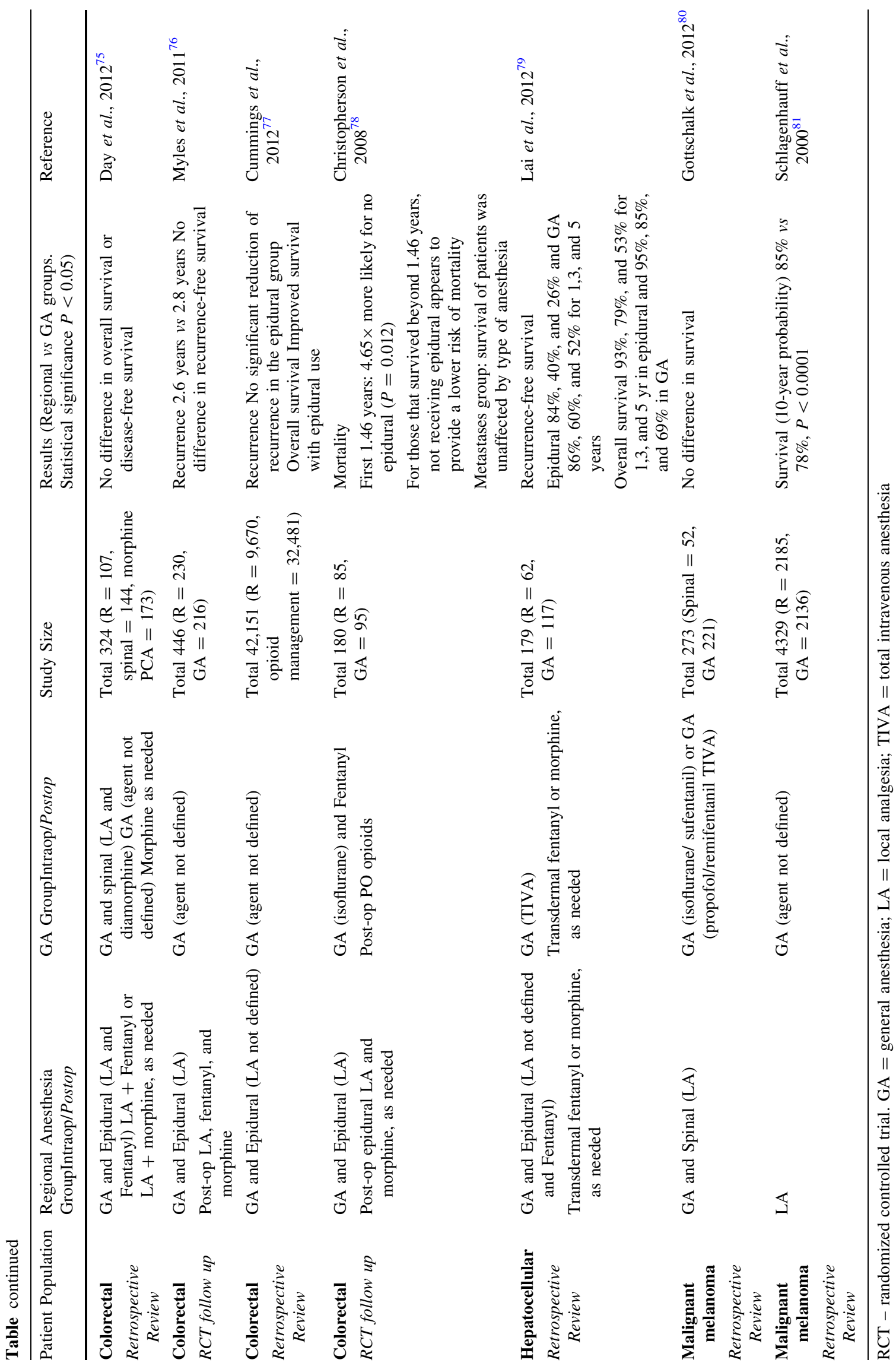




\section{PRE-OPISEDATION}

Low-dose fentanyl $\mathbf{P}$

Propofol ? $\mathscr{}$

Low-dose $(0.2 \mathrm{mg} / \mathrm{kg})$ ketamine $? \mathscr{A}$

Gabapentin -

Dexmedetomidine ?ะs

Benzodiazepine ?ץ

Remifentanil ?:

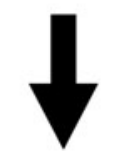

\section{INDUCTION}

Lidocaine $\mathscr{}$

Low-dose fentanyl $\mathbf{P}$

Propofol ?

Muscle relaxant -

High-dose $(2 \mathrm{mg} / \mathrm{kg})$ ketamine ?

\section{$\downarrow$}

\section{MAINTENANCE}

Regional anesthesia $\mathscr{}$

Propofol $\mathbf{P}$

Beta-blockers ?

Muscle relaxant -

Anticholinergic -

Inhalational agents ?\$

Opioids ?\$

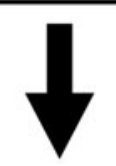
POST-OP
Anti-emetics
Ondansetron ?
Droperidol ?
Metoclopramide ? $\mathscr{V}$
Dimenhydrinate -
Dexamethasone $\mathbf{P s}$ (and should be reserved for rescue)

\section{Analgesia}
Regional anesthesia $\mathscr{}$
NSAID (e.g., ketorolac) $\mathscr{}$
Acetaminophen ?
Tramadol $\boldsymbol{P} \mathscr{}$
Low-dose $(0.2 \mathrm{mg} / \mathrm{kg})$ ketamine $?$
Opioids ?* (morphine > fentanyl > buprenorphine)

4 Fig. 3 The flow chart summarizes the most common drugs used during the perioperative period. Please note that the flow chart is constructed based on the author's own understanding and interpretation of the current literature. Our understanding of the immune system is evolving, and it appears that most agents have both immunosuppressive and immune up-regulating effects, and it is the balance of these effects that potentially tip the effect of each agent in favour of suppression or up-regulation. We do not have definitive answers at this time, and the reader should be cautioned and encouraged to formulate their own opinion based on the current literature as knowledge in this field advances. Legend: $(\boldsymbol{})$ indicates no strong evidence against use in terms of immunosuppression; $((\boldsymbol{x}))$ indicates evidence present; (-) indicates no published literature; (? $\boldsymbol{V})$ indicates limited or no evidence; $(?(\mathbf{x}))$ indicates limited or no evidence, but questionable

Fig. 3 L'organigramme répertorie les médicaments le plus fréquemment utilisés au cours de la période périopératoire. Veuillez noter que l'organigramme est construit selon la propre compréhension et interprétation des publications actuelles par l'auteur. Notre connaissance du système immunitaire évolue constamment et il apparaît que la plupart des molécules ont, à la fois, des effets immunosuppresseurs et de régulation à la hausse; c'est l'équilibre entre ces effets qui fait éventuellement pencher l'action globale d'un médicament vers la suppression ou la régulation à la hausse. Nous n'avons pas de réponses définitives à ce jour et le lecteur doit être mis en garde et encouragé à former sa propre opinion en fonction des publications actuelles au fur et à mesure de la progression des connaissances. Légende: $(\boldsymbol{})$ indique qu'il n'existe pas de données probantes fortes contre l'utilisation en termes d'immunosuppression; $((x))$ indique que des données probantes existent; (-) indique qu'il n'existe pas d'article publié; (? $\boldsymbol{\vee}$ ) indique que les données probantes sont limitées ou inexistantes; (?(x)) indique des données probantes limitées - mais douteuses - ou inexistantes

\section{Discussion}

Perioperative modulation of immune system components involved in the process of tumour elimination has been demonstrated in both animal and human laboratory research models. Multiple factors are associated with immune modulation, including magnitude of surgery, stress response, hypothermia, blood transfusion, perioperative pain and anxiety, and individual anesthetic agents. Nevertheless, the clinical significance of this suppression in terms of cancer recurrence and patient survival remains unknown due to conflicting clinical evidence.

Interpreting the significance of laboratory-based evidence without supporting clinical evidence is challenging. The results of immune function tests from peripheral blood samples or in-vitro cell experiments do not provide the full picture of the complex interaction between immune cells, surrounding factors, and tumor elimination cells in patients. Caution must therefore be exercised when interpreting laboratory evidence to guide clinical practice.

Current laboratory evidence suggests that individual anesthetic agents can affect immune factors. Of these agents, 
opiates and inhaled anesthetics are most widely implicated, and effects seem to be dose-dependent. It has therefore been suggested that a 'minimally immunosuppressive' regime that avoids these agents may improve cancer outcome. If a minimally immunosuppressive regimen has a clinical benefit, it is possible that only a small number of patients falling into subgroups based on genetic, immunological, and cancer profiles will benefit. No adequately powered prospective clinical trials have been completed, and ongoing trials are underpowered to detect such a difference. Therefore, it is unlikely that conclusive clinical evidence will emerge in the near future.

At this time, it must be emphasized that robust clinical evidence indicating a survival benefit of one anesthetic technique over another is unavailable. The role of pain and anxiety in immunosuppression appears to be greater than the effects of individual anesthetic drugs. In animal models, the analgesic effects of opiates appear to offer an overall benefit by controlling pain, thereby reducing stress and anxiety. When using an opiate analgesic regime, the addition of an NSAID or COX-2 inhibitor may have a beneficial role in decreasing angiogenesis and metastatic spread by inhibiting PGE2 production, and appears to have the additional advantages of an opiate-sparing effect and decreased opiate-induced NK cell suppression. Inhalational agents have been shown to cause modulation of CMI but may also confer some benefit through other immunological pathways. The implications of giving a one-time preemptive dose of dexamethasone for PONV are unknown. The risk of suppression of thymic function should be considered before administering dexamethasone routinely. Prevention of PONV remains a priority, but other methods such as a propofol-based anesthetic technique, regional anesthesia, and administration of alternative anti-emetics provide effective options (Fig. 3).

We are left to interpret the available evidence until more definitive clinical answers are provided. What do we tell the anxious patient who has read about this subject on the internet and now presents to the anesthetic pre-assessment clinic with a list of questions? How do we plan our next anesthetic for a patient presenting with cancer? A pragmatic solution is to utilize anesthetic drugs and techniques that have proven efficacy and also compare favourably in laboratory research. Regional anesthesia in isolation or combined with propofol infusion addresses the fundamental goals of controlling post-operative pain and reducing PONV while exerting minimal immunomodulatory effects, based on current laboratory evidence and immunological theory.

\section{Clinical case}

A 40-yr-old woman is scheduled for mastectomy and node dissection. She presents to the pre-admission clinic, and assessment reveals that she is otherwise healthy. She appears to be concerned about laboratory research implicating opiates and volatile agents in immunosuppression. She reaches into her purse and produces several reference papers. On questioning, you discover that she is a high school biology teacher with an undergraduate degree in immunology.

\section{Instructions for completing the continuing professional development (CPD) module:}

1. Read the current article and the three references indicated in bold.

2. Go to: http://www.cas.ca/Members/CPD-Online and select the current module (Impact of Anesthesia for Cancer Surgery).

3. Answer the multiple choice questions regarding the case scenario.

4. Once you have entered all of your answers, you will have access to experts' explanations for all the possible choices.

5. Participants may claim up to four hours of CPD, for a total of twelve credits under Section 3 of the CPD program of the Royal College of Physicians and Surgeons of Canada.

\section{Impact de l'anesthésie sur la chirurgie oncologique}

\section{Résumé}

Objectif Un certain nombre de publications originales et d'articles de synthèse ont abordé le problème de la modulation immunitaire et de l'évolution du cancer. L'objectif de ce module est de passer en revue les connaissances actuelles entourant les voies impliquées et les données probantes impliquant les agents anesthésiques couramment utilisés.

Constatations principales Il a été démontré que les médicaments couramment utilisés en anesthésie affectent différentes composantes du système immunitaire chez les animaux de laboratoire et dans des modèles humains in vitro. L'hypothèse a été formulée que ces effets pourraient favoriser la récidive des tumeurs et la formation de métastases. Les agents inhalés et les morphiniques ont des effets immunomodulateurs potentiellement négatifs; en revanche, l'anesthésie locorégionale et le propofol peuvent avoir des effets positifs sur la modulation de la fonction immunitaire. Cependant, la pertinence clinique de ces études par rapport 
à l'évolution du cancer chez l'être humain est inconnue dans la mesure où les essais cliniques sont équivoques et que les résultats d'études sur des modèles animaux et in vitro ne peuvent pas être extrapolés à la pratique clinique. En outre, nous manquons d'essais cliniques rigoureux démontrant l'avantage d'une technique par rapport à une autre sur l'évolution clinique. La façon dont les anesthésiques influencent le système immunitaire pour ce qui concerne l'élimination des cellules tumorales et l'évolution clinique d'un cancer reste mal comprise.

Conclusions Il n'est pas possible de faire des recommandations en faveur d'une technique anesthésique spécifique sur la seule base de l'évolution d'un cancer. Une solution pragmatique consisterait à proposer aux patients atteints de cancer une anesthésie locorégionale seule ou associée à une perfusion de propofol si c'est indiqué et si l'expertise locale est disponible. L'anesthésie locorégionale offre une excellente analgésie, une faible incidence de nausées et vomissements postopératoires, ainsi qu'un profil immunologique favorable selon les données probantes actuelles de laboratoire dont nous disposons.

\section{Objectifs de ce module de développement professionnel continu (DPC):}

Après avoir lu ce module, le lecteur devrait être capable de:

1. Décrire les voies impliquées dans la modulation immunitaire en périopératoire;

2. Identifier les médicaments anesthésiques et analgésiques habituellement utilisés qui sont associés à une altération de l'immunité à médiation cellulaire;

3. Évaluer les limites des données cliniques et de laboratoire actuelles dans ce domaine;

4. Informer les patients sur notre connaissance actuelle du sujet.

Le concept d'immuno-surveillance du cancer a été proposé dans les années $1950,{ }^{1}$ et il est aujourd'hui reconnu que le système immunitaire joue un rôle protecteur important contre la croissance du cancer. ${ }^{2}$ L'élimination des cellules tumorales par le système immunitaire implique l'immunité à médiation cellulaire (IMC) comportant l'activation des phagocytes, des lymphocytes $\mathrm{T}$ cytotoxiques et la libération de cytokines aboutissant à la destruction des cellules tumorales. La recherche menée en laboratoire sur des modèles animaux et humains in vitro indique l'existence d'une altération de l'IMC après chirurgie et la suppression du système immunitaire au cours de la période périopératoire pourrait être suffisante pour permettre aux cellules tumorales d'échapper à l'immuno-surveillance et de produire des métastases. ${ }^{3}$ La réponse au stress chirurgical, la douleur, l'anxiété, l'hypothermie, les transfusions sanguines et les médicaments anesthésiants sont les facteurs périopératoires que l'on pense responsables de l'immunosuppression. ${ }^{4,5}$ Ainsi, des facteurs différents modulent l'action du système immunitaire vers une évolution plus positive ou plus négative du cancer.

L'hypothèse d'un lien possible entre la technique d'anesthésie et l'évolution du cancer chez les humains a été formulée en 1977 après une analyse rétrospective de 1358 cas de patientes atteintes d'un cancer du sein. ${ }^{6}$ Les taux de survie des patientes recevant de l'halothane étaient de beaucoup supérieurs à ceux des patientes recevant de l'éther. En 2006, une étude rétrospective de 129 patientes subissant une mastectomie et un curage axillaire pour cancer du sein a conclu que la récidive et la survie sans métastase était significativement supérieure dans le groupe ayant bénéficié d'une analgésie paravertébrale que dans le groupe ayant eu une analgésie à base de morphine. ${ }^{7}$ Ces études ont été suivies par plusieurs articles, de sciences fondamentales, de sciences clinique et de synthèse en rapport avec cette question; néanmoins, la question reste la suivante: jusqu'où nos connaissances sur les rapports entre l'anesthésie, le système immunitaire et le cancer ont-elles progressé?

Afin de déterminer la signification clinique de la technique d'anesthésie, il faut passer en revue les hypothèses actuelles faisant un lien entre les facteurs de stress périopératoire, d'une part, et l'immunomodulation et la croissance de métastases, d'autre part. Il est également important de comprendre les défis auxquels sont confrontés les chercheurs dans ce domaine ainsi que les limites des données probantes cliniques et de laboratoire. Dans ce module, nous étudions à la fois les données de sciences fondamentales et les données cliniques sous l'angle de la relation entre les médicaments donnés en anesthésie et en période périopératoire d'une part et la fonction immunitaire et le cancer d'autre part. Le but est de jeter un éclairage sur les connaissances requises pour informer pleinement les patients de notre compréhension du sujet et pour guider la pratique clinique.

\section{Immuno-surveillance et modulation tumorale - une introduction aux composants clés}

La réponse au stress neuro-humoral

Une réponse inflammatoire aiguë apparaît au site du traumatisme chirurgical (Fig. 1). Quand la douleur est transmise au système nerveux central, l'activation de l'hypothalamus et du système nerveux sympathique entraine une élévation du cortisol plasmatique, des catécholamines, de l'acétylcholine et des peptides avec 
une dépression secondaire à la fois des cellules de l'immunité innée (cellules tueuses naturelles [NK - un sous-groupe de lymphocytes $\mathrm{T}$ cytotoxiques], monocytes, macrophages et cellules dendritiques) et des cellules spécifiques de l'IMC (lymphocytes T CD8 cytotoxiques et lymphocytes T CD4 auxiliaires). ${ }^{8}$ Les lymphocytes T CD4 auxiliaires incluent les sous-groupes Th1 et Th2: les cellules Th1 renforcent la réponse à médiation cellulaire d'élimination des cellules tumorales tandis que les cellules Th2 facilitent une réponse humorale, médiée par des anticorps, qui ne joue aucun rôle dans l'élimination de la tumeur (Fig. 2). Un rapport Th1/Th2 augmenté indique une réponse immunitaire à médiation cellulaire améliorée et serait potentiellement bénéfique pour l'élimination de la tumeur, alors qu'un rapport abaissé pourrait favoriser la progression tumorale. Les cytokines seront produites par la majorité des cellules nucléées, y compris celles qui sont impliquées dans l'IMC en réponse à des facteurs d'agression tels qu'un traumatisme ou une infection. La production des cytokines dépend du type de réponse immunitaire et certaines cytokines, comme l'IFN-gamma, l'IL-2 et le $\mathrm{TNF}$, sont associées à une réponse cellulaire médiée par les cellules Th1. En revanche, des cytokines, telles qu'IL4, IL6, IL10 et IL13, sont associées à des réponses d'anticorps Th2. La prostaglandine E2 (PGE2), un produit de la voie de la cyclo-oxygénase (COX), module le système immunitaire en supprimant de façon sélective la fonction des macrophages, des neutrophiles, des cellules Th1 et des cellules NK, tout en facilitant la réponse des cellules Th2.

\section{Angiogenèse}

La chirurgie peut avoir pour conséquence une dispersion des cellules tumorales dans les vaisseaux sanguins et lymphatiques. Ces cellules ont la capacité de former des métastases dans les lits capillaires d'organes distants. Pour qu'une tumeur survive au-delà d'un diamètre de $2 \mathrm{~mm}$, il doit y avoir une angiogenèse. ${ }^{9}$ Le facteur de croissance de l'endothélium vasculaire (Vascular Endothelial Growth Factor - VEGF) est l'une des nombreuses cytokines connues pour jouer un rôle important dans ce processus.

La croissance du cancer du sein métastatique inclut des périodes de dormance temporaire et la résection chirurgicale de la tumeur primitive peut perturber ces périodes de dormance, aboutissant à une récidive. La baisse de la production des facteurs d'antiangiogenèse angiostatine et endostatine consécutive au retrait de la tumeur primitive entraîne une augmentation des taux de VEGF, favorisant ainsi l'angiogenèse. La libération de métalloprotéinases de la matrice (MMP) au cours de la chirurgie augmente également la motilité des cellules malignes libres et leur potentiel invasif, ${ }^{10}$ contribuant à la croissance des métastases. Les études chez l'animal ont montré que l'inhibition de l'activité du récepteur du VEGF peut réduire les métastases hépatiques d'un cancer du côlon. ${ }^{11}$ L'inhibition de l'angiogenèse a également été utilisée en pratique clinique avec un certain succès, mais de nombreux patients ont une maladie réfractaire. Chez d'autres, les tumeurs développent rapidement une résistance aux facteurs antiangiogéniques et des événements indésirables liés aux médicaments peuvent également empêcher la réussite du traitement. Des polymorphismes d'un seul nucléotide du gène VEGF peut modifier les concentrations de la protéine VEGF chez certains patients, avec un impact sur l'angiogenèse. ${ }^{12}$ Ces polymorphismes pourraient alors expliquer la variabilité de l'évolution clinique des tumeurs angiogenèse-dépendantes, tels que les cancers du sein, les cancers du poumon autres que ceux à petites cellules, le cancer colorectal $^{13}$ et le cancer de la prostate.

\section{Molécules et techniques directement impliquées dans l'immunosuppression - Données probantes de la recherche fondamentale}

Agents d'induction

\section{Thiopental}

Il a été démontré que le thiopental avait des propriétés immunosuppressives dans des études de chez l'homme et chez l'animal. Les études chez l'homme révèlent des diminutions dose-dépendantes de la prolifération des lymphocytes $\mathrm{T}^{14}$ et une dépression de la cytolyse des monocytes, ${ }^{15}$ alors que les études chez l'animal montrent une augmentation significative de la rétention tumorale ${ }^{16,17}$ et un nombre réduit de cellules NK cellules comparativement aux témoins. ${ }^{16}$

\section{Propofol}

Le propofol pourrait avoir un profil d'immunomodulation plus favorable que les autres agents d'induction pour ce qui concerne la modulation de l'IMC. Aucune réduction significative du rapport Th1/Th2 n'a été observée quand le propofol était utilisé pour l'entretien de l'anesthésie chez les patients subissant une craniotomie. ${ }^{18}$ Il a été également montré que le propofol le supprime la production de PGE2 par les monocytes via un effet sur l'activité de la cyclo-oxygénase.

\section{Étomidate}

Les données probantes sont limitées mais en faveur d'un effet négatif de l'étomidate sur le système immunitaire. 
Une étude chez l'homme a montré une réduction dose-dépendante de la prolifération des lymphocytes $\mathrm{T}$ après exposition à l'étomidate. ${ }^{14}$

\section{Kétamine}

Les données probantes concernant la kétamine sont équivoques. Une étude chez l'homme a montré qu'une faible dose de kétamine administrée avant l'induction d'une anesthésie évitait une inhibition significative de la prolifération lymphocytaire. ${ }^{19}$ Les effets immunologiques semblent être dose-dépendants. Des études chez l'animal ont montré une augmentation significative de la rétention des tumeurs du poumon avec des doses plus importantes; ${ }^{16}$ toutefois, un prétraitement aux bêta-bloqueurs a réduit cet effet, suggérant une implication des propriétés intrinsèques de stimulation adrénergique de la kétamine. Dans un autre modèle animal, des concentrations plus élevées de kétamine ont entraîné une suppression de la phagocytose des macrophages et de la capacité oxydative en plus d'une réduction du potentiel de membrane mitochondriale, aboutissant à un dysfonctionnement des mitochondries. ${ }^{20}$

\section{Benzodiazépines}

Les données concernant l'effet des benzodiazépines sur la fonction immunitaire sont limitées; toutefois, les anxiolytiques devraient avoir un effet globalement bénéfique sur l'immunité par le biais d'une réduction du stress. Un modèle animal a montré une diminution des métastases de carcinome pulmonaire de Lewis chez des sources anxieuses, mais pas chez des souris non anxieuses, après un traitement au diazépam. ${ }^{21}$

Agents inhalés

Les agents inhalés ont été habituellement associés à une réduction de l'IMC. Des études chez l'homme ont montré une réduction significative du rapport $\mathrm{Th} 1 / \mathrm{Th} 2$ avec l'isoflurane comparativement au propofol. ${ }^{18}$ Des expériences in vitro ont révélé les dommages causés à l'ADN dans des lymphocytes humains du sang périphérique de façon dose-dépendante après une exposition à l'halothane, l'isoflurane, le sevoflurane et le desflurane. Les anesthésiques volatils sont connus pour entrainer une régulation à la hausse de l'expression des facteurs induits par une hypoxie. Ces facteurs sont importants pour le maintien de la fonction cellulaire normale dans des conditions hypoxiques, mais également associés à la tumorigenèse et à un mauvais pronostic du cancer. ${ }^{22,23}$

Le sevoflurane pourrait avoir des avantages par rapport aux agents inhalés plus anciens. Une réponse abaissée au stress (mesuré par des dosages de l'hormone adrénocorticotrope, du cortisol et de l'hormone de croissance) était évidente quand le sevoflurane était comparé à l'isoflurane pour une chirurgie pelvienne laparoscopique. ${ }^{24}$ Les agents inhalés peuvent également avoir des effets bénéfiques; dans un modèle animal, un préconditionnement avec du sevoflurane et du desflurane a été associé à une réduction de la libération de la métalloprotéinase-9 matricielle par des neutrophiles humains isolés et les diminutions de l'invasion par des cellules de cancer colorectal.

\section{Antalgiques}

\section{Morphiniques}

Il a été montré, dans des modèles animaux, que la morphine augmentait la suppression des cellules NK et augmentait la charge tumorale après la chirurgie. ${ }^{25} \mathrm{La}$ suppression des cellules NK est dose-dépendante et l'ampleur de l'effet varie selon les morphiniques utilisés (morphine $>$ fentanyl $>$ buprénorphine). ${ }^{26}$ Il est intéressant de noter que le kétorolac et l'interleukine 2 bloquent la suppression des cellules NK. ${ }^{25}$ Dans un autre modèle animal, deux semaines de traitement répété avec de la morphine ont entraîné une stimulation de la COX-2 et de la PGE2, une augmentation du poids de la tumeur, une augmentation des métastases et une réduction de la survie. Ces effets ont été évités par l'administration concomitante de célécoxib. ${ }^{27}$

Dans les études chez l'homme, l'administration intrathécale de morphine $(0,5 \mathrm{mg})$ a supprimé l'activité des cellules NK au premier jour postopératoire, avec une récupération dès le deuxième jour. La suppression n'a pas été observée avec une dose de $0,1 \mathrm{mg}$ de morphine, suggérant un effet dose-dépendant. ${ }^{28}$ L'administration de fentanyl a été associée à une augmentation transitoire du nombre de cellules $\mathrm{NK},{ }^{29}$ une réduction dose-dépendante de l'activité des cellules $\mathrm{NK}^{30}$ ou à une absence de réduction. ${ }^{31} \mathrm{Le}$ remifentanil n'a pas paru perturber l'activité des cellules NK chez des volontaires en bonne santé. ${ }^{32}$

La plupart des effets immunitaires de la morphine sont perdus chez les souris knockout pour le récepteur $\mathrm{Mu}$ des morphiniques (MOR) indiquant que ce récepteur MOR est la voie principale d'une immunosuppression directe. Une activation des récepteur MOR au niveau central active les voies descendantes de l'axe hypothalamo-hypophysaire et du système nerveux sympathique (SNS) entraînant une immunomodulation. ${ }^{33}$ Le variant mu3 du récepteur est sensible à la morphine mais pas au fentanyl. Il a été montré que la morphine avait un effet négatif sur la fonction des neutrophiles, un effet également observé avec le fentanyl. ${ }^{34}$ Un lien possible a été fourni par l'observation suivante: le méthylnaltrexone (antagoniste du récepteur mu périphérique) 
inhibe l'angiogenèse induite par le VEGF sous l'action de la morphine et réduit également chez l'homme la croissance in vitro de tumeurs du sein, du côlon et du rectum, et du poumon autres que celles à petites cellules. ${ }^{34}$

Il a été montré que des doses cliniquement pertinentes de morphine favorisaient la néovascularisation tumorale et augmentaient la progression tumorale dans un modèle de souris porteuses de xénogreffes de tumeurs du sein humaines. $^{35}$ Les morphiniques peuvent également stimuler l'angiogenèse et induisent une anomalie de la fonction des barrières (en augmentant la perméabilité vasculaire), permettant ainsi - potentiellement - la pénétration des cellules tumorales. ${ }^{36}$

\section{Anti-inflammatoires non stérö̈diens (AINS)}

Les données probantes en faveur de l'utilisation des AINS en chirurgie oncologique sont sans aucun doute des plus solides. Ces médicaments et les inhibiteurs sélectifs de la COX-2, incluant le célécoxib, inhibent la production de PGE2. Dans un modèle de cancer du sein chez la souris, le célécoxib a empêché certains des effets indésirables associés à l'utilisation chronique de morphine, tels que l'augmentation du poids de la tumeur, l'accroissement des métastases et la diminution de la survie. De plus, l'indométacine a diminué de $50 \%$ les métastases pulmonaires d'un adénocarcinome mammaire associées à la chirurgie dans un modèle murin. L'indométacine associée à un bêta bloqueur a réduit les métastases de $75 \%$. Des études supplémentaires ont montré que la PGE2 et les agonistes bêta augmentaient, de façon indépendante, les métastases et supprimaient l'activité des cellules $\mathrm{NK} .^{25,37-39}$

\section{Acétaminophène}

Aucune publication n'a été identifiée pour ce qui concerne l'acétaminophène et l'immunosuppression.

\section{Tramadol}

Le tramadol est un agoniste du récepteur mu des morphiniques ainsi qu'un inhibiteur de la recapture de la sérotonine et de la noradrénaline. Il pourrait être plus intéressant que la morphine et la codéine en termes d'effets immunologiques. Une revue des modèles animaux a montré une augmentation de l'activité des cellules NK et une augmentation de la prolifération lymphocytaire après administration de tramadol. ${ }^{33}$ Contrairement à la morphine, on n'a pas montré que le tramadol provoquait de réduction dose-dépendante de l'activité phagocytaire des cellules polymorphonucléaires périphériques et des monocytes chez l'homme au cours d'études in vitro. ${ }^{40}$ Sacerdote et al. ${ }^{41}$ ont indiqué que qu'un traitement postopératoire au tramadol ramenait la prolifération lymphocytaire (qui était déprimée après chirurgie) à des niveaux préopératoires chez des patients subissant une chirurgie abdominale, mais cela n'a pas été constaté avec la morphine. Cette étude a également démontré que l'activité des cellules NK était améliorée dans le groupe tramadol.

\section{Gabapentine}

Le gabapentin est un antiépileptique qui est également utilisé pour traiter les douleurs neuropathiques. Aucune publication n'a été identifiée pour ce qui concerne la gabapentine et l'immunosuppression.

Agents anesthésiques locaux

Des expériences in vitro ont montré que les anesthésiques locaux étaient cytotoxiques à fortes concentrations. On estime que la durée de l'exposition à un anesthésique local et la liposolubilité du médicament sont des facteurs importants. $^{42}$ Cependant, la pertinence de cette constatation en termes de modulation du cancer n'est pas claire dans la mesure où, en pratique clinique, l'infiltration ou la perfusion intraveineuse d'anesthésique local n'est pas associée à une concentration ni à une durée suffisantes pour provoquer la mort de la cellule tumorale. Une étude chez l'homme a comparé une perfusion peropératoire de lidocaïne à un placebo (sérum physiologique) chez des patientes subissant une hystérectomie par voie abdominale; les auteurs ont trouvé que les scores de douleur et la production de cytokines étaient inférieurs dans le groupe lidocaïne, tandis que la réponse proliférative lymphocytaire était plus importante que dans le groupe témoin. ${ }^{43}$ Il a été également démontré que les anesthésiques locaux de type amide inhibaient la migration des cellules d'adénocarcinome pulmonaire. ${ }^{44}$

Anesthésie locorégionale

Une méta-analyse des études qui ont évalué la fonction des cellules NK dans le contexte d'une anesthésie neuraxiale a suggéré l'existence à la fois d'effets positifs et d'effets négatifs sur la fonction cellulaire avec un impact globalement neutre. ${ }^{45}$ La combinaison d'une anesthésie générale et d'une anesthésie péridurale pour une hépatectomie s'est avérée plus efficace qu'une anesthésie générale seule pour l'amélioration de la réponse des cellules $\mathrm{Th}^{46}$ et, dans une étude chez l'animal, l'addition d'un bloc médullaire à une anesthésie générale pour laparotomie a contribué à restaurer l'activité des cellules mononucléées du foie (y compris les cellules NK et les cellules $\mathrm{T} \mathrm{NK}$ ), réduisant ainsi le risque de métastases induites par la chirurgie. ${ }^{47}$ 
Autres médicaments

\section{Béta-bloqueurs}

Il a été suggéré qu'un blocage bêta périopératoire pouvait jouer un rôle pour améliorer la fonction immunitaire postopératoire pour atténuer l'activation du SNS. Dans un modèle animal, le blocage bêta 1 et bêta 2 a eu un effet additif dans la prévention de la suppression de l'activité des cellules NK et dans l'augmentation de la résistance aux métastases NK-sensibles. ${ }^{48}$

\section{Antiémétiques}

La dexaméthasone est connue pour supprimer la fonction du thymus, induisant une atrophie de l'organe et provoquant des modifications dans les pourcentages, à la fois relatifs et absolus, du nombre de thymocytes. ${ }^{49}$ Une revue systématique sur la dexaméthasone a conclu qu'une dose unique administrée en prévention des nausées et vomissements postopératoires supprime toutes les fonctions des cellules immunitaires pendant une courte période. ${ }^{50} \mathrm{Il}$ a été démontré que la dexaméthasone réduisait la production de PGE2 au niveau de l'incision chirurgicale, ce qui peut indirectement soutenir une fonction lymphocytaire. ${ }^{51}$ Aucune donnée probante n'a été trouvée concernant les antagonistes du récepteur 5-HT3 de la sérotonine ou des antagonistes du récepteur $\mathrm{H} 1$ de l'histamine, d'une part, et l'immunosuppression, d'autre part. Il a été démontré que le métoclopramide restaurait la fonction immunitaire après une immunosuppression et un sepsis induits par une hémorragie traumatique. ${ }^{51-53}$ Il a été démontré que le droperidol n'avait pas d'effet indésirable sur la création de dérivés réactifs de l'oxygène par les lymphocytes $\mathrm{T}^{54}$ Les inhibiteurs de la substance $\mathrm{P}$ sont de plus en plus disponibles au Canada pour la prophylaxie des nausées et vomissements postopératoires chez les patients à haut risque. Il s'agit d'antagonistes des récepteurs de la neurokine $1(\mathrm{NK} 1)^{55}$ qui modulent également la transmission de la douleur dans la corne dorsale, procurant un avantage supplémentaire en termes d'analgésie. Les cellules des cancers du sein expriment les récepteurs NK1 et les antagonistes des NK1bloquent une voie supplémentaire impliquée dans la prolifération et la migration des cellules tumorales, ainsi que dans l'angiogenèse, faisant de ce groupe d'antiémétiques un sujet d'intérêt pour des recherches complémentaires.

\section{Inhibiteurs de la pompe à protons/antagonistes du récepteur $\mathrm{H} 2$}

Les inhibiteurs de la pompe à protons réduisent l'activité bactéricide des neutrophiles et inhibent l'activité des cellules NK. En revanche, la ranitidine favorise l'activité des cellules NK et augmente le rapport Th1/Th2. ${ }^{56-59}$ Une étude randomisée prospective portant sur des patients subissant une chirurgie abdominale a trouvé que la ranitidine réduisait la diminution postopératoire de l'activité des cellules NK, spontanée et stimulée, mais qu'elle ne modifiait pas de façon significative le rapport Th1/Th2 ou les réponses des cellules mononucléaires. ${ }^{57}$

Agonistes des récepteurs adrénergiques alpha-2

Les récepteurs alpha-2 sont exprimés dans les cellules de tumeurs du sein et leur stimulation est associée à un accroissement de la prolifération cellulaire. ${ }^{9}$ La clonidine diminue in vitro l'activité des cellules NK comparativement au fentanyl.

\section{Curares}

Il n'existe pas de données probantes en faveur d'un effet direct des curares sur le système immunitaire.

Technique et prise en charge chirurgicales

On estime que l'ampleur du traumatisme chirurgical est liée au degré de réponse au stress, à l'immunosuppression secondaire et au pronostic. ${ }^{60} \mathrm{Chez}$ des patients ayant un carcinome des cellules rénales, une néphrectomie radicale par voie laparoscopique a été associée à une immunosuppression significativement moindre qu'en cas de néphrectomie radicale par chirurgie ouverte. ${ }^{61}$ D'autres études ont démontré les avantages sur la fonction immunitaire et l'évolution du cancer de la chirurgie thoracoscopique assistée par vidéo par rapport à la thoracotomie ouverte. ${ }^{60}$ Des concentrations élevées de cellules tumorales dans le sang ont été trouvées chez environ $30 \%$ des patients après résection chirurgicale ou radiothérapie pour carcinome hépatocellulaire. ${ }^{62}$

La transfusion sanguine peut provoquer une suppression des cellules CD4 et CD8. ${ }^{34}$

L'hypothermie diminue la migration des lymphocytes, réduit la phagocytose des neutrophiles et favorise une bascule vers les cellules $\operatorname{Th} 2 .^{34}$

\section{Molécules et techniques directement impliquées dans l'immunosuppression - preuves cliniques}

La possibilité que l'IMC influence l'évolution du cancer a été soulignée dans une étude prospective évaluant la récidive de la maladie et la survie chez 77 patientes ayant subi une mastectomie totale. ${ }^{63}$ Le pronostic a été comparé aux réponses de l'IMC chez des patientes aux antigènes autologues associés à la tumeur (TAA; des protéines qui 
sont exprimées différemment dans les cellules cancéreuses par rapport aux cellules normales) au cours de la période postopératoire précoce. Vingt et une (21) patientes ont présenté une réponse de l'IMC positive pour les TAA autologues. Une seule patiente est décédée de maladie métastatique. Cinquante-six (56) patientes avaient une réponse de l'IMC négative et 23 sont décédées d'une maladie métastatique. Il semble, par conséquent, que certaines patientes puissent être plus à risque de développer des récidives de la maladie et des métastases en fonction de la réponse immunitaire à médiation cellulaire dirigée contre les TAA autologues. Il peut y avoir un sous-groupe de patients chez lesquels la fonction de l'IMC est prédictive de l'évolution à long terme.

Les données cliniques probantes soutenant les avantages de l'anesthésie locorégionale en termes d'évolution et de récidive du cancer sont contradictoires et reposent sur un mélange de revues rétrospectives et de suivis d'essais cliniques randomisés qui étaient conçus à l'origine pour répondre à différentes hypothèses. La principale source qui a soulevé l'intérêt était une étude rétrospective comparant les résultats chez des patientes subissant une mastectomie et ayant eu une anesthésie générale combinée soit avec une anesthésie/analgésie paravertébrale, soit avec une analgésie morphinique en postopératoire. 88 Le délai sans récidive et/ ou métastases à 24 mois était de $94 \%$ dans le groupe paravertébral, comparée à $82 \%$ dans le groupe morphine; les taux de survie étaient de $94 \%$ et $77 \%$ à 36 mois, suggérant un avantage potentiel pour le groupe paravertébral. Dans une étude rétrospective sur des patients ayant un cancer de la prostate invasif subissant une prostatectomie radicale ouverte sous anesthésie générale, soit avec analgésie péridurale, soit avec analgésie à base de morphiniques, le risque de récidive a été inférieur dans le groupe péridurale. ${ }^{64}$ Un avantage a également été constaté dans des études rétrospectives sur des mélanomes et des cancers de l'ovaire, du foie, du côlon et du rectum. Il est à noter que d'autres études rétrospectives ont été publiées, montrant qu'il n'y avait aucune différence entre l'anesthésie locorégionale et l'anesthésie générale (voir le Tableau). Les analyses de suivi d'essais cliniques randomisés menés antérieurement n'ont pas montré de différences pour la chirurgie de la prostate et des résultats contradictoires pour la chirurgie colorectale.

Des données épidémiologiques probantes montrent que l'utilisation d'aspirine et d'autres AINS est associée à une réduction de l'incidence des tumeurs malignes, y compris des cancers du sein. ${ }^{65}$ Une étude rétrospective chez des patientes ayant un cancer du sein subissant une mastectomie a suggéré que l'utilisation peropératoire de kétorolac était associée à un taux de récidive moindre du cancer. $^{66}$

\section{Discussion}

La modulation périopératoire des composantes du système immunitaire impliquées dans le processus d'élimination tumorale a été démontrée dans des modèles de recherche animaux et humains en laboratoire. De nombreux facteurs sont associés à la modulation immunitaire, y compris l'ampleur de la chirurgie, la réponse au stress, l'hypothermie, la transfusion sanguine, la douleur périopératoire et l'anxiété, ainsi que les agents anesthésiques utilisés. Néanmoins, la signification clinique de cette suppression en termes de récidive du cancer et de survie des patients reste inconnue en raison des données probantes cliniques contradictoires.

L'interprétation de la signification des données de laboratoires sans preuves cliniques allant dans le même sens constitue un défi. Les résultats des tests de la fonction immunitaire réalisés sur des échantillons de sang périphérique ou des expérimentations menées sur des cellules in vitro ne fournissent pas un tableau complet des interactions complexes entre les cellules immunitaires, les facteurs environnants et l'élimination des cellules tumorales chez les patients. Il y a donc lieu de faire preuve de prudence lorsqu'il s'agit d'interpréter des données de laboratoire pour servir de guide à la pratique clinique.

Actuellement, les données de laboratoire probantes suggèrent que certains agents anesthésiques peuvent affecter les facteurs de l'immunité. Parmi ces agents, les morphiniques et les anesthésiques inhalés sont le plus largement impliqués et leurs effets semblent être dose-dépendants. Il a donc été suggéré qu'un protocole thérapeutique «immunosuppresseur a minima» qui éviterait d'inclure ces molécules pourrait améliorer l'évolution du cancer. Si un protocole thérapeutique immunosuppresseur a minima apporte un bénéfice clinique, il est possible que seulement un petit groupe de patients entrant dans des sous-groupes basés sur des profils génétiques, immunologiques et cancéreux, en profitera. Aucun essai clinique prospectif disposant de la puissance suffisante n'a été terminé et les essais en cours n'ont pas la puissance voulue pour détecter une telle différence. Il est donc peu probable de voir paraître dans un avenir proche des données cliniques définitives.

Actuellement, il faut insister sur le fait que nous ne disposons pas de preuves cliniques robustes indiquant un bénéfice en faveur d'une technique d'anesthésie par rapport à une autre sur la survie. Le rôle de la douleur et de l'anxiété dans l'immunosuppression semble être supérieur aux effets des médicaments anesthésiques individuels. Dans des modèles animaux, les effets analgésiques des morphiniques semblent offrir un bénéfice global sur le contrôle de la douleur, réduisant ainsi le stress et l'anxiété. Lors de l'utilisation d'un protocole d'analgésie à base de 


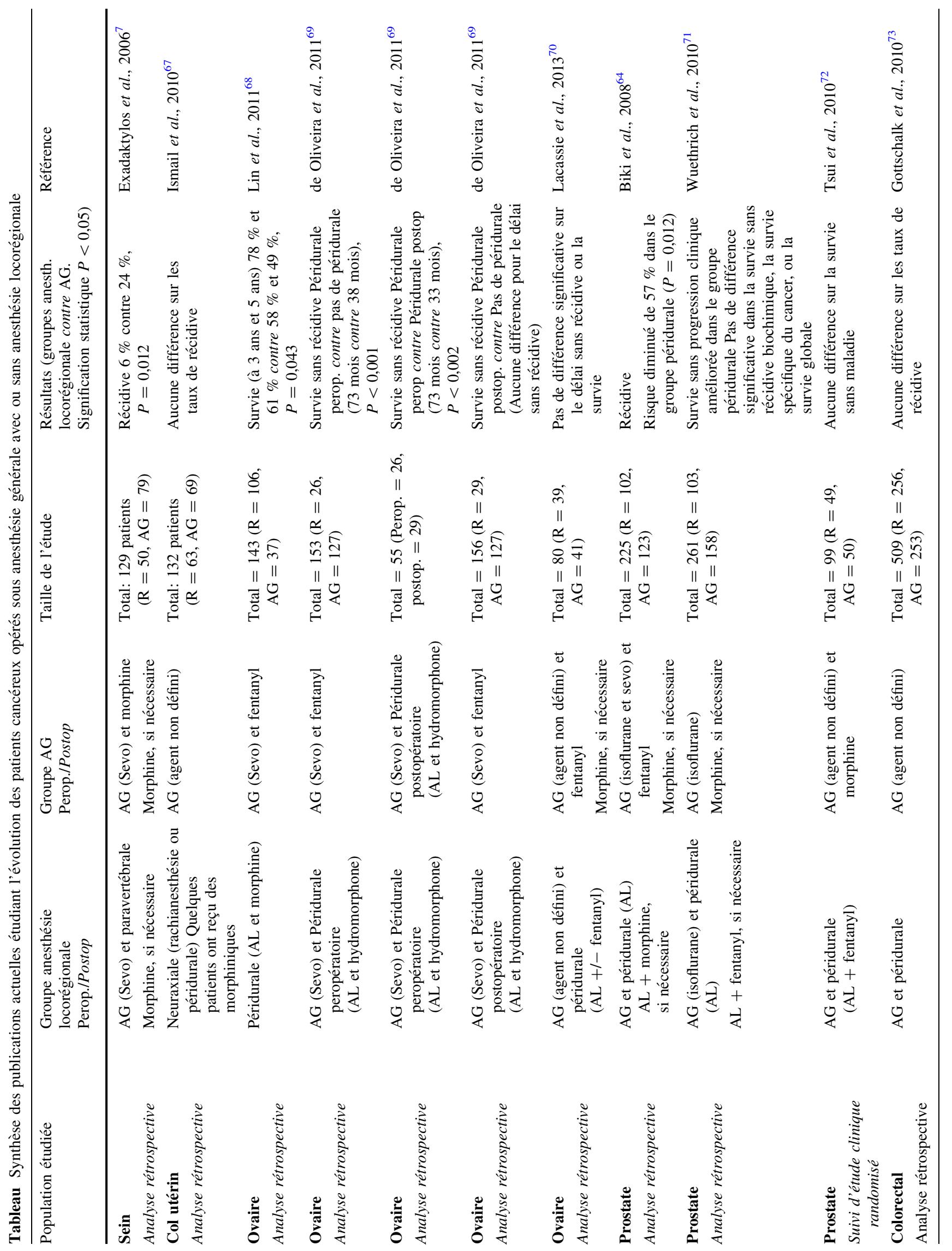




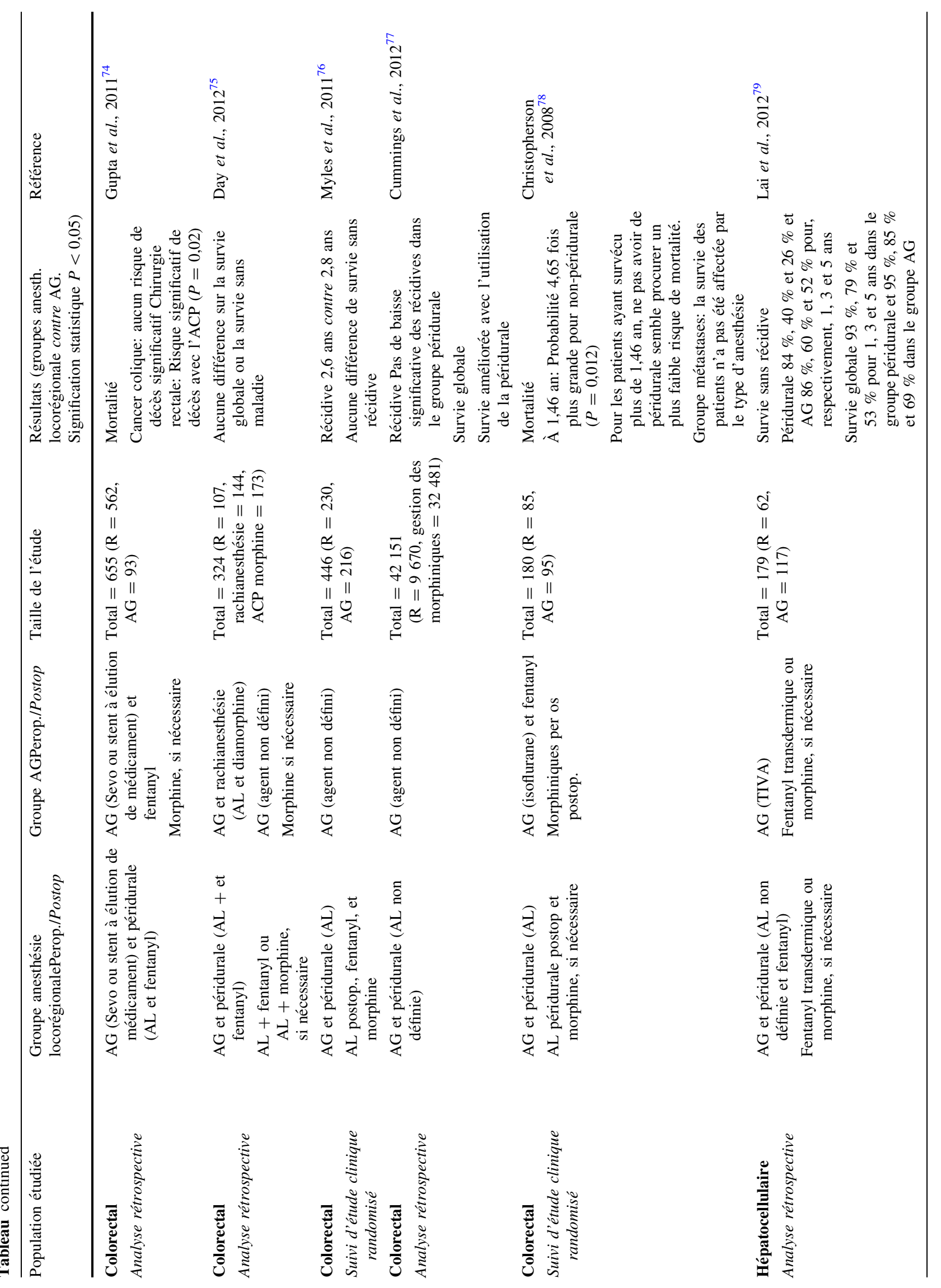


morphiniques, l'ajout d'un AINS ou d'un inhibiteur de la COX2 peut jouer un rôle bénéfique dans la diminution de l'angiogenèse et de la dispersion des métastases, en inhibant la production de PGE2; cet ajout semble aussi avoir un effet supplémentaire d'épargne des morphiniques et de baisse de la suppression des cellules NK induite par les morphiniques. Il a été montré que les agents inhalés entraînaient une modulation de l'IMC, mais qu'ils pouvaient aussi apporter un certain bénéfice via d'autres voies immunologiques. Les conséquences de l'administration d'une dose unique de dexaméthasone pour la prévention des nausées et vomissements postopératoires sont inconnues. Le risque de la suppression de la fonction thymique doit être pris en compte avant l'administration régulière de dexaméthasone. La prévention des nausées et vomissements postopératoires reste une priorité, mais d'autres méthodes comme la technique anesthésique reposant sur le propofol, l'anesthésie locorégionale et l'administration d'autres antiémétiques constituent des options efficaces (Fig. 3).

Il nous reste à interpréter les données probantes disponibles jusqu'à ce que des réponses cliniques plus définitives soient fournies. Que pouvons-nous dire au patient anxieux qui s'est informé sur ce sujet sur internet et qui se présente maintenant à la clinique pour l'évaluation pré-anesthésique avec une liste de questions? Comment planifions-nous notre prochaine anesthésie pour un patient ayant un cancer? Une solution pragmatique consiste à utiliser les médicaments anesthésiques qui se sont avérés efficaces et qui ont fait leurs preuves dans les recherches de laboratoires. Une anesthésie locorégionale d'isolement ou combinée à une perfusion de propofol répond aux objectifs fondamentaux de contrôle de la douleur postopératoire et de réduction des nausées et vomissements postopératoires, tout en ayant des effets immunomodulateurs minimes si l'on se base sur les données de laboratoire actuellement disponibles et la théorie de l'immunologie.

\section{Cas clinique}

Une femme de 40 ans doit subir une mastectomie et un évidement ganglionnaire. Elle se présente à la clinique de pré-admission et l'évaluation révèle qu'elle est par ailleurs en bonne santé. Elle semble préoccupée par les recherches de laboratoire impliquant les morphiniques et les agents volatils dans l'immunosuppression. Elle sort de son sac à main plusieurs articles de référence. En la questionnant, vous découvrez qu'elle enseigne la biologie à l'école secondaire et qu'elle a un diplôme universitaire de premier cycle en immunologie. 


\section{Directives pour compléter le module de développement professionnel continu (DPC):}

1. Lisez le présent article et les trois références bibliographiques indiquées en gras.

2. Allez à la page: http://www.cas.ca/Membres/ modules-de-DPC et sélectionnez le module actuel (Impact de l'anesthésie sur la chirurgie oncologique).

3. Répondez aux questions à choix multiple concernant le cas proposé.

4. Une fois que vous avez saisi toutes vos réponses, vous aurez accès aux explications des experts sur tous les choix possibles.

5. Les participants peuvent réclamer un maximum de quatre heures de DPC, pour un total de douze crédits au titre de la section 3 du programme de DPC du Collège royal des médecins et chirurgiens du Canada.

Acknowledgements The authors thank Dr. Gareth Corry, Dr. Derek Dillane, and Darren Lam for assistance with manuscript preparation.

Conflicts of interest None declared.

Funding sources Dr. Tsui is supported by a Clinical Scholar Award from the Alberta Heritage Foundation for Medical Research (AHFMR)

\section{Conflits d'intérêts Aucun déclaré.}

Sources de financement Le Dr Tsui est soutenu par une bourse d'études cliniques de la Fondation Alberta Heritage Foundation for Medical Research (AHFMR).

\section{References}

1. Burnet M. Cancer; a biological approach. I. The processes of control. Br Med J 1957; 1: 779-86.

2. Dunn GP, Old LJ, Schreiber RD. The three Es of cancer immunoediting. Annu Rev Immunol 2004; 22: 329-60.

3. Neeman E, Ben-Eliyahu $S$. Surgery and stress promote cancer metastasis: new outlooks on perioperative mediating mechanisms and immune involvement. Brain Behav Immun 2013; 30(Suppl): S32-40.

4. Shakhar G, Ben-Eliyahu S. Potential prophylactic measures against postoperative immunosuppression: could they reduce recurrence rates in oncological patients? Ann Surg Oncol 2003; 10: 972-92.

5. Snyder GL, Greenberg $S$. Effect of anaesthetic technique and other perioperative factors on cancer recurrence. $\mathrm{Br} J$ Anaesth 2010; 105: 106-15.

6. Fried IA. The influence of the anaesthetic on survival rates of breast cancer patients after surgery. Int J Cancer 1977; 20: 213-8.

7. Exadaktylos AK, Buggy DJ, Moriarty DC, Mascha E, Sessler DI. Can anesthetic technique for primary breast cancer surgery affect recurrence or metastasis? Anesthesiology 2006; 105: 660-4.

8. Tracey KJ. Reflex control of immunity. Nat Rev Immunol 2009; 9: $418-28$
9. Heaney A, Buggy DJ. Can anaesthetic and analgesic techniques affect cancer recurrence or metastasis? Br J Anaesth 2012; 109(Suppl 1): i17-28.

10. Kirman I, Jain $S$, Cekic $V$, et al. Altered plasma matrix metalloproteinase-9/tissue inhibitor of matrix [corrected] metalloproteinase- 1 concentration during the early postoperative period in patients with colorectal cancer. Surg Endosc 2006; 20: 482-6.

11. Shaheen RM, Davis DW, Liu W, et al. Antiangiogenic therapy targeting the tyrosine kinase receptor for vascular endothelial growth factor receptor inhibits the growth of colon cancer liver metastasis and induces tumor and endothelial cell apoptosis. Cancer Res 1999; 59: 5412-6.

12. Jain L, Vargo CA, Danesi $R$, et al. The role of vascular endothelial growth factor SNPs as predictive and prognostic markers for major solid tumors. Mol Cancer Ther 2009; 8: 2496-508.

13. Price N. Vascular endothelial growth factors $\mathrm{C}$ and $\mathrm{D}$ in colorectal cancers. Clin Colorectal Cancer 2004; 4: 23-5.

14. Devlin EG, Clarke RS, Mirakhur RK, McNeill TA. Effect of four i.v. induction agents on T-lymphocyte proliferations to PHA in vitro. Br J Anaesth 1994; 73: 315-7.

15. Hole A. Depression of monocytes and lymphocytes by stressrelated humoral factors and anaesthetic-related drugs. Acta Anaesthesiol Scand 1984; 28: 280-6.

16. Melamed R, Bar-Yosef S, Shakhar G, Shakhar K, Ben-Eliyahu S. Suppression of natural killer cell activity and promotion of tumor metastasis by ketamine, thiopental, and halothane, but not by propofol: mediating mechanisms and prophylactic measures. Anesth Analg 2003; 97: 1331-9.

17. Shapiro J, Jersky J, Katzav S, Feldman M, Segal S. Anesthetic drugs accelerate the progression of postoperative metastases of mouse tumors. J Clin Invest 1981; 68: 678-85.

18. Inada T, Yamanouchi Y, Jomura S, et al. Effect of propofol and isoflurane anaesthesia on the immune response to surgery. Anaesthesia 2004; 59: 954-9.

19. Beilin B, Rusabrov Y, Shapira $Y$, et al. Low-dose ketamine affects immune responses in humans during the early postoperative period. Br J Anaesth 2007; 99: 522-7.

20. Chang $Y$, Chen $T L$, Sheu JR, Chen RM. Suppressive effects of ketamine on macrophage functions. Toxicol Appl Pharmacol 2005; 204: 27-35.

21. Kaledin VI, Llnitskaya SI, Nikolin VP, Popova NA, Smagin DA, Kudryavtseva NN. Limiting effect of diazepam on Lewis Lung carcinoma metastasis in anxious male mice. Exp Oncol 2009; 31: 62-4.

22. Benzonana LL, Perry NJ, Watts HR, et al. Isoflurane, a commonly used volatile anesthetic, enhances renal cancer growth and malignant potential via the hypoxia-inducible factor cellular signaling pathway in vitro. Anesthesiology 2013; 119: 593-605.

23. Tavare AN, Perry NJ, Benzonana LL, Takata M, Ma D. Cancer recurrence after surgery: direct and indirect effects of anesthetic agents. Int J Cancer 2012; 130: 1237-50.

24. Marana E, Annetta MG, Meo F, et al. Sevoflurane improves the neuroendocrine stress response during laparoscopic pelvic surgery. Can J Anesth 2003; 50: 348-54.

25. Colacchio TA, Yeager MP, Hildebrandt $L W$. Perioperative immunomodulation in cancer surgery. Am J Surg 1994; 167: 174-9.

26. Franchi $S$, Panerai AE, Sacerdote P. Buprenorphine ameliorates the effect of surgery on hypothalamus-pituitary-adrenal axis, natural killer cell activity and metastatic colonization in rats in comparison with morphine or fentanyl treatment. Brain Behav Immun 2007; 21: 767-74.

27. Farooqui $M, \mathrm{Li}$ Y, Rogers $T$, et al. COX-2 inhibitor celecoxib prevents chronic morphine-induced promotion of angiogenesis, tumour growth, metastasis and mortality, without compromising analgesia. Br J Cancer 2007; 97: 1523-31. 
28. Yokota T, Uehara K, Nomoto $Y$. Intrathecal morphine suppresses NK cell activity following abdominal surgery. Can $J$ Anesth 2000; 47: 303-8.

29. Yeager MP, Procopio MA, DeLeo JA, Arruda JL, Hildebrandt L, Howell $A L$. Intravenous fentanyl increases natural killer cell cytotoxicity and circulating CD16(+) lymphocytes in humans. Anesth Analg 2002; 94: 94-9.

30. Beilin B, Shavit $Y$, Hart J, et al. Effects of anesthesia based on large versus small doses of fentanyl on natural killer cell cytotoxicity in the perioperative period. Anesth Analg 1996; 82: 492-7.

31. Yardeni IZ, Beilin B, Mayburd E, Alcalay $Y$, Bessler $H$. Relationship between fentanyl dosage and immune function in the postoperative period. J Opioid Manag 2008; 4: 27-33.

32. Cronin AJ, Aucutt-Walter NM, Budinetz T, et al. Low-dose remifentanil infusion does not impair natural killer cell function in healthy volunteers. Br J Anaesth 2003; 91: 805-9.

33. Sacerdote $P$. Opioid-induced immunosuppression. Curr Opin Support Palliat Care 2008; 2: 14-8

34. Kurosawa $S$. Anesthesia in patients with cancer disorders. Curr Opin Anaesthesiol 2012; 25: 376-84.

35. Gupta K, Kshirsagar S, Chang L, et al. Morphine stimulates angiogenesis by activating proangiogenic and survival-promoting signaling and promotes breast tumor growth. Cancer Res 2002; 62: 4491-8.

36. Singleton PA, Moreno-Vinasco L, Sammani S, Wanderling SL, Moss $J$, Garcia JG. Attenuation of vascular permeability by methylnaltrexone: role of mOP-R and S1P3 transactivation. Am J Respir Cell Mol Biol 2007; 37: 222-31.

37. Melamed R, Rosenne E, Shakhar K, Schwartz Y, Abudarham N, Ben-Eliyahu S. Marginating pulmonary-NK activity and resistance to experimental tumor metastasis: suppression by surgery and the prophylactic use of a beta-adrenergic antagonist and a prostaglandin synthesis inhibitor. Brain Behav Immun 2005; 19: 114-26.

38. Page $G G$, Ben-Eliyahu $S$. Indomethacin attenuates the immunosuppressive and tumor-promoting effects of surgery. J Pain 2002; 3: 301-8.

39. Yakar I, Melamed $R$, Shakhar $G$, et al. Prostaglandin e(2) suppresses NK activity in vivo and promotes postoperative tumor metastasis in rats. Ann Surg Oncol 2003; 10: 469-79.

40. Beilin B, Grinevich $G$, Yardeni IZ, Bessler H. Tramadol does not impair the phagocytic capacity of human peripheral blood cells. Can J Anesth 2005; 52: 1035-9.

41. Sacerdote P, Bianchi M, Gaspani L, et al. The effects of tramadol and morphine on immune responses and pain after surgery in cancer patients. Anesth Analg 2000; 90: 1411-4.

42. Krog J, Hokland M, Ahlburg P, Parner E, Tonnesen E. Lipid solubility- and concentration-dependent attenuation of in vitro natural killer cell cytotoxicity by local anesthetics. Acta Anaesthesiol Scand 2002; 46: 875-81.

43. Yardeni IZ, Beilin B, Mayburd E, Levinson Y, Bessler $H$. The effect of perioperative intravenous lidocaine on postoperative pain and immune function. Anesth Analg 2009; 109: 1464-9.

44. Piegeler T, Votta-Velis EG, Liu G, et al. Antimetastatic potential of amide-linked local anesthetics: inhibition of lung adenocarcinoma cell migration and inflammatory Src signaling independent of sodium channel blockade. Anesthesiology 2012; 117: 548-59.

45. Conrick-Martin I, Kell MR, Buggy DJ. Meta-analysis of the effect of central neuraxial regional anesthesia compared with general anesthesia on postoperative natural killer $\mathrm{T}$ lymphocyte function. J Clin Anesth 2012; 24: 3-7.

46. Zhou D, Gu FM, Gao Q, Li QL, Zhou J, Miao CH. Effects of anesthetic methods on preserving anti-tumor T-helper polarization following hepatectomy. World $\mathrm{J}$ Gastroenterol 2012; 18: 3089-98.
47. Wada H, Seki S, Takahashi T, et al. Combined spinal and general anesthesia attenuates liver metastasis by preserving TH1/TH2 cytokine balance. Anesthesiology 2007; 106: 499-506.

48. Ben-Eliyahu S, Shakhar G, Page GG, Stefanski V, Shakhar K. Suppression of NK cell activity and of resistance to metastasis by stress: a role for adrenal catecholamines and beta-adrenoceptors. Neuroimmunomodulation 2000; 8: 154-64.

49. Frawley $R$, White $K J r$, Brown $R$, Musgrove D, Walker $N$, Germolec D. Gene expression alterations in immune system pathways in the thymus after exposure to immunosuppressive chemicals. Environ Health Perspect 2011; 119: 371-6.

50. Henzi I, Walder B, Tramer MR. Dexamethasone for the prevention of postoperative nausea and vomiting: a quantitative systematic review. Anesth Analg 2000; 90: 186-94.

51. Knoferl MW, Angele MK, Ayala A, Cioffi WG, Bland KI, Chaudry $I H$. Insight into the mechanism by which metoclopramide improves immune functions after trauma-hemorrhage. Am J Physiol Cell Physiol 2000; 279: C72-80.

52. Oberbeck R, Schmitz D, Wilsenack $K$, et al. Metoclopramide and cellular immune functions during polymicrobial sepsis. Eur Surg Res 2004; 36: 116-22.

53. Zellweger $R$, Wichmann $M W$, Ayala A, Chaudry $I H$. Metoclopramide: a novel and safe immunomodulating agent for restoring the depressed macrophage immune function after hemorrhage. J Trauma 1998; 44: 70-7.

54. Delogu G, Antonucci A, Moretti S, et al. Oxidative stress and mitochondrial glutathione in human lymphocytes exposed to clinically relevant anesthetic drug concentrations. J Clin Anesth 2004; 16: 189-94.

55. Munoz $M$, Rosso $M$, Casinello $F$, Covenas $R$. Paravertebral anesthesia: how substance P and the NK-1 receptor could be involved in regional block and breast cancer recurrence. Breast Cancer Res Treat 2010; 122: 601-3.

56. Mikawa K, Akamatsu $H$, Nishina $K$, et al. The effects of cimetidine, ranitidine, and famotidine on human neutrophil functions. Anesth Analg 1999; 89: 218-24.

57. Nielsen HJ, Pedersen BK, Moesgaard F, Haahr PM, Kehlet $H$. Effect of ranitidine on postoperative suppression of natural killer cell activity and delayed hypersensitivity. Acta Chir Scand 1989; 155: 377-82.

58. Noble $D W$. Proton pump inhibitors and stress ulcer prophylaxis: pause for thought? Crit Care Med 2002; 30: 1175-6.

59. Scaringi L, Cornacchione $P$, Fettucciari $K$, et al. Activity inhibition of cytolytic lymphocytes by omeprazole. Scand J Immunol 1996; 44: 204-14.

60. Whitson BA, D'Cunha J, Maddaus MA. Minimally invasive cancer surgery improves patient survival rates through less perioperative immunosuppression. Med Hypotheses 2007; 68: 1328-32.

61. Peng B, Zheng JH, Li $\mathrm{H}$. Effect of retroperitoneal laparoscopic radical nephrectomy of renal carcinoma (nephroma) on perioperative cell immunity. J Endourol 2008; 22: 2161-4.

62. Wong IH, Yeo W, Leung T, Lau WY, Johnson PJ. Circulating tumor cell mRNAs in peripheral blood from hepatocellular carcinoma patients under radiotherapy, surgical resection or chemotherapy: a quantitative evaluation. Cancer Lett 2001; 167: 183-91.

63. Mccoy JL, Rucker R, Petros JA. Cell-mediated immunity to tumor-associated antigens is a better predictor of survival in early stage breast cancer than stage, grade or lymph node status. Breast Cancer Res Treat 2000; 60: 227-34.

64. Biki B, Mascha E, Moriarty DC, Fitzpatrick JM, Sessler DI, Buggy DJ. Anesthetic technique for radical prostatectomy surgery affects cancer recurrence: a retrospective analysis. Anesthesiology 2008; 109: 180-7.

65. Davies $G$, Martin LA, Sacks N, Dowsett M. Cyclooxygenase-2 (COX-2), aromatase and breast cancer: a possible role for COX-2 
inhibitors in breast cancer chemoprevention. Ann Oncol 2002; 13: $669-78$

66. Forget $P$, Vandenhende $J$, Berliere $M$, et al. Do intraoperative analgesics influence breast cancer recurrence after mastectomy? A retrospective analysis. Anesth Analg 2010; 110: 1630-5.

67. Ismail H, Ho KM, Narayan K, Kondalsamy-Chennakesavan S. Effect of neuraxial anaesthesia on tumour progression in cervical cancer patients treated with brachytherapy: a retrospective cohort study. Br J Anaesth 2010; 105: 145-9.

68. Lin L, Liu C, Tan H, Ouyang H, Zhang Y, Zeng W. Anaesthetic technique may affect prognosis for ovarian serous adenocarcinoma: a retrospective analysis. Br J Anaesth 2011; 106: 814-22.

69. de Oliviera GS, Ahmad S Jr, Schink JC, Singh DK, Fitzgerald $P C, M c$ Carthy RJ. Intraoperative neuraxial anesthesia but not postoperative neuraxial analgesia is associated with increased relapse-free survival in ovarian cancer patients after primary cytoreductive surgery. Reg Anesth Pain Med 2011; 36: 271-7.

70. Lacassie HJ, Cartagena J, Branes J, Assel M, Echevarria GC. The relationship between neuraxial anesthesia and advanced ovarian cancer-related outcomes in the Chilean population. Anesth Analg 2013; 117: 653-60.

71. Wuethrich PY, Hsu Schmitz SF, Kessler TM, et al. Potential influence of the anesthetic technique used during open radical prostatectomy on prostate cancer-related outcome: a retrospective study. Anesthesiology 2010; 113: 570-6.

72. Tsui BC, Rashiq S, Schopflocher D, et al. Epidural anesthesia and cancer recurrence rates after radical prostatectomy. Can J Anesth 2010; 57: 107-12.

73. Gottschalk A, Ford JG, Regelin CC, et al. Association between epidural analgesia and cancer recurrence after colorectal cancer surgery. Anesthesiology 2010; 113: 27-34.
74. Gupta A, Bjornsson A, Fredriksson M, Hallbook O, Eintrei C. Reduction in mortality after epidural anaesthesia and analgesia in patients undergoing rectal but not colonic cancer surgery: a retrospective analysis of data from 655 patients in central Sweden. Br J Anaesth 2011; 107: 164-70.

75. Day A, Smith R, Jourdan I, Fawcett W, Scott M, Rockall T. Retrospective analysis of the effect of postoperative analgesia on survival in patients after laparoscopic resection of colorectal cancer. Br J Anaesth 2012; 109: 185-90.

76. Myles PS, Peyton P, Silbert B, et al. Perioperative epidural analgesia for major abdominal surgery for cancer and recurrencefree survival: randomised trial. BMJ 2011; 342: d1491.

77. Cummings $K C 3 r d, X u F$, Cummings LC, Cooper GS. A comparison of epidural analgesia and traditional pain management effects on survival and cancer recurrence after colectomy: a population-based study. Anesthesiology 2012; 116: 797-806.

78. Christopherson R, James KE, Tableman M, Marshall P, Johnson $F E$. Long-term survival after colon cancer surgery: a variation associated with choice of anesthesia. Anesth Analg 2008; 107 : 325-32.

79. Lai $R$, Peng $Z$, Chen $D$, et al. The effects of anesthetic technique on cancer recurrence in percutaneous radiofrequency ablation of small hepatocellular carcinoma. Anesth Analg 2012; 114: 290-6.

80. Gottschalk A, Brodner G, Van Aken HK, Ellger B, Althaus S, Schulze HJ. Can regional anaesthesia for lymph-node dissection improve the prognosis in malignant melanoma? $\mathrm{Br} \mathrm{J}$ Anaesth 2012; 109: 253-9.

81. Schlagenhauff $B$, Ellwanger $U$, Breuninger $H$, Stroebel $W$, Rassner $G$, Garbe $C$. Prognostic impact of the type of anaesthesia used during the excision of primary cutaneous melanoma. Melanoma Res 2000; 10: 165-9. 